\title{
SUSTAINABILITY ANALYSIS OF THE APPLICATION OF WASTE BANK IN ELEMENTARY SCHOOL WITH A MULTIDIMENSIONAL SCALING APPROACH
}

\author{
Lili Mulyana $^{1 *}$, Yonik Meilawati Yustiani ${ }^{1}$, Reyhan Reiyana Andisa ${ }^{1}$, Raja Faisal Ramadhan ${ }^{1}$, Diny \\ Hidayanti $^{2}$ \\ ${ }^{1}$ Department of Environmental Engineering, Faculty of Engineering, Pasundan University, Indonesia \\ ${ }^{2}$ Ar Rafi' Elementary School, Bandung, Indonesia
}

\begin{abstract}
Waste banks are one of the waste management that have the potency to reduce the burden of waste in the final processing site. Until now, there is a large number of waste banks to accommodate waste from the surrounding environment. Bandung, as a city that experienced a waste emergency in 2005, has encouraged its citizens to operate waste banks, both school scale, neighborhood and for a larger scope. Bandung City Government also cooperates with several waste banks to conduct several programs to increase public awareness of environmental cleanliness. Waste banks that have been built mostly do not come with good management, so some waste banks are only feasible quickly. The purpose of this study is to obtain a waste bank management model based on existing conditions using the Multidimensional Scaling Method. This method exploring data provides a visual picture of the proximity patterns in the form of similarities or distances between a set of objects. This method will be useful for the formulation of waste bank sustainability recommendations in its marketing strategy and diversification of its business without reducing the essence of waste banks as part of environmental management. The representation of the waste bank that was used as the object of the study was the Rafi' Elementary School Waste Bank. Data processing uses Rapfish/Rap-Bash software with multidimensional scale methods. Data processing results are used to formulate the sustainability strategy of waste banks.
\end{abstract}

Keywords: Management, Multidimensional scaling method, Waste bank

\section{Introduction}

Waste management in major cities has undergone a paradigm shift since Law No. 18 of 2008 on Waste Management with the main goal to maintain public health by managing waste properly. In addition, the need to change the new paradigm of waste management from the community, where waste as a resource with economic value and can be utilized. Regulation

*Email: lili.mulyatna@unpas.ac.id

Received: 30 August 2021

Revised: 18 September 2021

Accepted: 18 September 2021

DOI: $10.23969 /$ jcbeem.v5i2.4535 of the Minister of environment Number 13 of 2012 concerning Guidelines for the Implementation of Reduce, Reuse, and Recycle (3R) through waste banks explains that waste banks are places for sorting and collecting waste that can be recycled and or reused that have economic value, and the process involves the community (Yustiani., et al, 2019).

The $3 \mathrm{R}$ concept is a new paradigm in consumption and production patterns at all levels by giving the highest priority to waste management oriented to the prevention of waste, minimization of waste by encouraging reusable goods and biodegradable goods, and 
environmentally the application of environmentally friendly waste disposal. The implementation of $3 \mathrm{R}$ concerns social issues to encourage changes in attitudes and mindsets towards the realization of an environmentally friendly and sustainable society and concerns proper regulation (management) in its implementation.

Waste banks are now operating in many communities to support $3 \mathrm{R}$ program of government waste management. Schools contribute their part by developing and performing the waste banks, mainly for educational purposes. Ar Rafi' Elementary School is one of an educational place that conducting waste bank. Although it appears smooth run, waste banks operated in schools sustainability might not be in stable condition. Sustainability of waste bank operation, including by educational purposes need to be maintained (Triana \& Sembiring, 2018). This research was carried out to analyze the sustainability of school waste bank operation in Ar Rafi' Elementary School by using MDS.

Multidimensional Scaling (MDS) is a statistical analysis to determine the similarities and inaccuracies of variables depicted in geometric spaces. This MDS method was chosen because it is able to provide results thoroughly, quickly and objectively related to aspects that affect the sustainability of waste bank management, making it easier to implement in policy. This method has been widely used to identify the level of sustainability of natural resource management.

\section{Research Methodology}

The research method used is the survey method, which is an investigation held to obtain facts and find factual information about environmental, economic, social and institutional from an area. The main data collection techniques through the use of questionnaires and to strengthen and check the validity of the questionnaire results data is complemented by interviews with respondents, field observations, and collection of statistical data/reports, articles, and scientific publications. This research uses a gradual mix method or often called the sequential mixed method (Walker \& Baxter, 2019. In this strategy, researchers combine data found from one method with another. Research methods using qualitative methods followed by quantitative methods then end with interpretation (sequential exploratory).

\section{Tools and Materials}

The collection of data and information from various sources is done using several ways:

1. Literature studies and secondary data collection. Such as reports, documents, and publications published by relevant agencies and various journals, seminar materials, and previous research related to research topics.

2. Primary data collection. Such as discussion, in-depth interviews, questionnaire filling, and direct observation at the research site.

3. Sampling techniques. In order to dig up information and knowledge (acquisition of expert opinion) determined intentionally (purposive sampling)

\section{Critical Attributes Assignment}

Sustainability analysis of waste bank management covers four dimensions, namely: (1) ecology; (2) economic, (3) social, and (4) regulatory and institutional. The ecological dimension focuses on facilities and conditions in the waste bank environment. The economic dimension focuses on the financing aspect in the form of investment cost support and operational costs from the government and private / NGO. The social dimension focuses on aspects of community participation, knowledge, and public perception. The regulatory and institutional dimensions focus on the form of the institution, its legality, and its legal protection. 
Data processing was performed by using Rapfish application. The application can evaluate sustainability analysis for many fields (Nababan et al., 2007).

\section{Result and Discussion}

Critical Attribute Analysis of Waste Bank Implementation

The results of the evaluation of the implementation of waste banks in Rafi' Elementary School using Rapfish showed overall that the sustainability index for 4 dimensions was 59.16 (sustainable). Based on Table 1 it is seen that the ecological dimension has a sustainability index value of 80.02. This value is the highest compared to the other four dimensions of sustainability. While the economic dimension has the smallest sustainability index value of 26.95 .

Table 1. Sustainability Analysis in Rafi' Elementary School

\begin{tabular}{clccc}
\hline No. & $\begin{array}{c}\text { Sustainability } \\
\text { Dimension }\end{array}$ & \multicolumn{2}{c}{$\begin{array}{c}\text { Sustainability } \\
\text { Index Value } \\
(\%)\end{array}$} & $\begin{array}{c}\text { |MDS- } \\
\mathbf{M C} \mid \\
(\boldsymbol{\%})\end{array}$ \\
\cline { 3 - 5 } & & MDS & MC & $\Delta$ \\
\hline 1 & Ecology & 80.02 & 79.40 & 0.62 \\
\hline 2 & Economic & 26.95 & 29.11 & 2.16 \\
\hline 3 & Social & 49.88 & 50.40 & 0.52 \\
\hline 4 & $\begin{array}{l}\text { Regulatory \& } \\
\text { institutional }\end{array}$ & 79.78 & 79.13 & 0.65 \\
\hline \multicolumn{3}{c}{ Sum } & $\mathbf{5 9 . 1 6}$ & $\mathbf{5 9 . 5 1}$ \\
\hline
\end{tabular}

Description:

MDS = Multidimensional Scaling

MC = Monte Carlo

- $\quad=$ delta

The results of Monte Carlo analysis and MDS analysis at the level of $95 \%$ confidence obtained the difference in the value of the Sustainability Index of Waste Bank Implementation at Rafi' waste Bank in Bandung city $<3 \%$. This means that the resulting MDS analysis model is adequate to estimate the sustainability index value of the Rafi' Waste Bank.
In Table 2 displayed the results of the Rapfish analysis obtained the coefficient of determination $\left(\mathrm{R}^{2}\right)$ for the sustainability index of Rafi' Elementary School Waste Bank between $93 \%-95 \%$ or the value of this coefficient of determination is close to the value of $95-100 \%$ and the stress value is less than $25 \%$ (0.14-0.17), so that the MDS analysis model obtained has a high accuracy (goodness of fit) to assess the sustainability index of the implementation of Waste Bank at Rafi' Elementary School Waste Bank.

Table 2. Sustainability Analysis in Rafi' Elementary School

\begin{tabular}{clcc}
\hline \multirow{2}{*}{ No. } & $\begin{array}{c}\text { Sustainability } \\
\text { Dimension }\end{array}$ & Stress & $\begin{array}{c}\text { Coef. } \\
\text { Determination }\end{array}$ \\
\cline { 3 - 4 } & $\mathbf{S}$ & $\mathbf{R}^{2}$ \\
\hline 1 & Ecology & 0.1515 & 0.9385 \\
\hline 2 & Economic & 0.1394 & 0.9518 \\
\hline 3 & Social & 0.1717 & 0.9374 \\
\hline 4 & $\begin{array}{l}\text { Regulatory \& } \\
\text { institutional }\end{array}$ & 0.1519 & 0.9246 \\
\hline
\end{tabular}

\section{Ecology Dimension}

The index of the ordination results for the sustainability status of the implementation of waste banks in the Rafi' Waste Bank in Bandung on the ecological dimension, as a whole is $80.02 \%$ or in the category either because the value of the ecological dimension index falls into the range of 75.01-100.00 (very sustainable).

Based on monitoring in the field, the ecological conditions around the Rafi' Elementary School waste bank are relatively good. The location of the waste bank is very strategic because it is in the school environment so it is easily accessible. The waste bank building is on land bounded by a fence occupying a decent room equipped with adequate waste storage warehouses. So that does not disturb the local environment, although the source of waste is limited because it is located in the school environment. The environmental 
conditions of the waste bank encourage this ecological dimension will be sustainable in the future. Sustainability status of ecological dimension of Rafi' Elementary School Waste Bank in Bandung City presented in Figure 1.

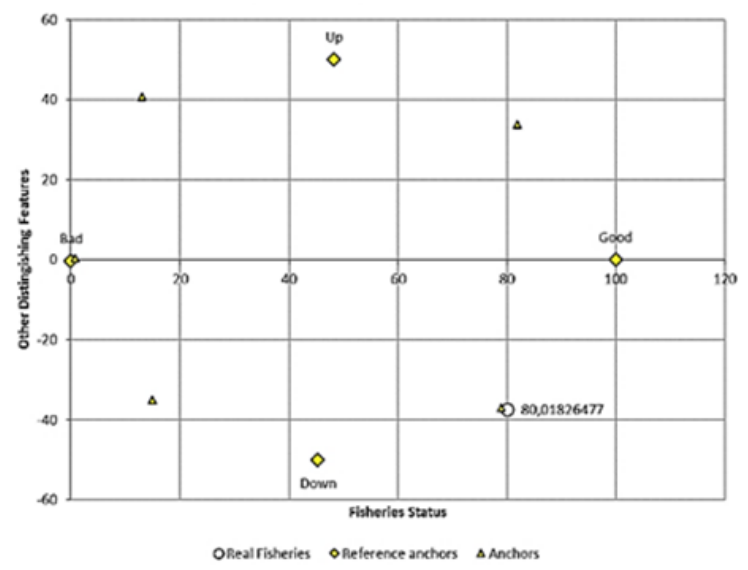

Figure 1. Sustainability Status Index of Ecological Dimensions

\section{Economic Dimension}

The index of the ordination results for the sustainability status of the implementation of waste banks in the Rafi' Elementary School Waste Bank in Bandung on the Economic dimension, as a whole is $26.95 \%$ or in the category is less good because the value of the Economic dimension index falls into the range of 25.01-50.00 (less sustainable).

Based on monitoring in the field, the benefits of the community/customers of Rafi' Waste Bank are economically existing but not significant so it cannot be relied upon to meet some daily needs. Likewise, with the benefits obtained by the manager of the waste bank, it is still inadequate so it cannot finance the operations of the waste bank. Based on these conditions, the Rafi' Elementary School Waste Bank still relies on the results of waste bank management. Diversification of business from a waste bank has not become a priority.

These conditions encourage this dimension of the economy tends to be less sustainable in the future. The sustainability status of the economic dimension of Rafi' Elementary School Waste Bank in Bandung City is presented in Figure 2.

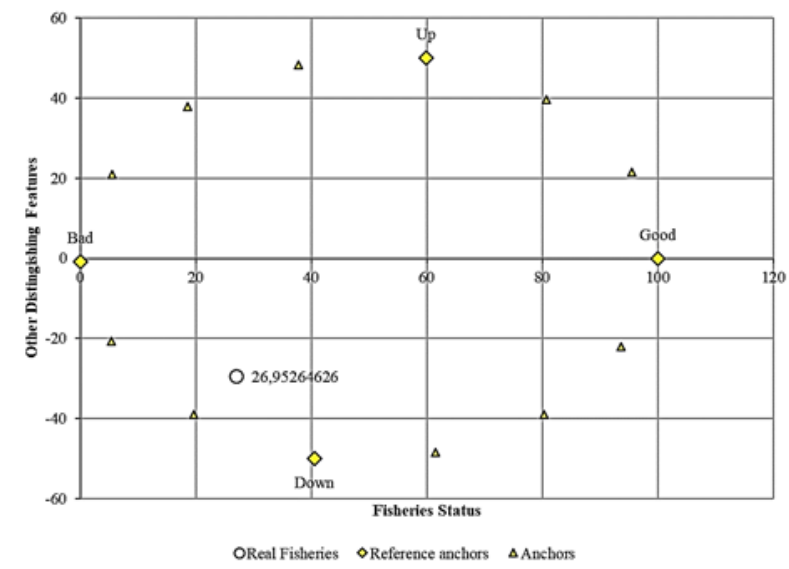

Figure 2. Sustainability Status Index of Economic Dimensions

\section{Social Dimension}

The index of ordination results for the sustainability status of the implementation of waste banks in Rafi' Elementary School in Bandung on the Social dimension, as a whole is $49.88 \%$ or in the category of less good because the value of the Social dimension index falls into the range of 25.01-50.00 (less sustainable).

Based on monitoring in the field, student participation in The Rafi' Elementary School Waste Bank Bandung still needs to be improved both at the formation stage, building a schoolbased waste management system. In addition, the percentage of students involved is still not optimal even though the knowledge is sufficient and perception is quite good, but the continuity of customers in saving has not been consistent. These conditions encourage this social dimension to be quite sustainable in the future. Sustainability status of social dimension of Rafi' Elementary School Waste Bank ini Bandung city presented in Figure 3. 


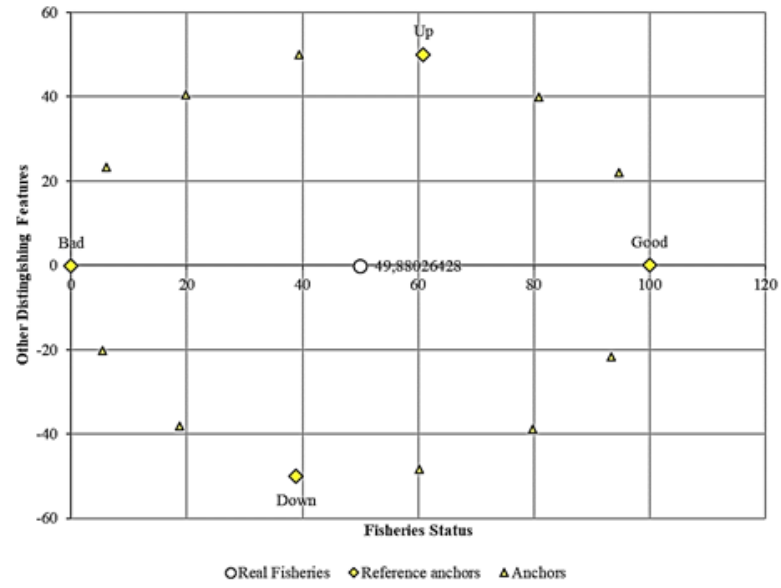

Figure 3. Sustainability Status Index of Social Dimensions

\section{Regulatory and Institutional Dimension}

The index of the ordination results for the sustainability status of the implementation of waste banks in The Rafi' Elementary School in Bandung on the dimension of Regulations and Institutions, as a whole is $79.78 \%$ or in the category is very good because the value of the Regulatory and Institutional dimension index falls into the range of 75.01-100.00 (very sustainable).

Based on monitoring in the field, regulations and legislation related to the management of waste banks both at the national, provincial, and city/ district levels are complete, including guidelines in the management of school-based waste banks In addition, the institution of waste bank management has been formed and active, namely The Rafi' Elementary School Waste Bank in Bandung. These conditions encourage this regulatory and institutional dimension to be very sustainable in the future. Sustainability status of the regulatory and institutional dimensions of Rafi' Elementary School Waste Bank in Bandung is presented in Figure 4.

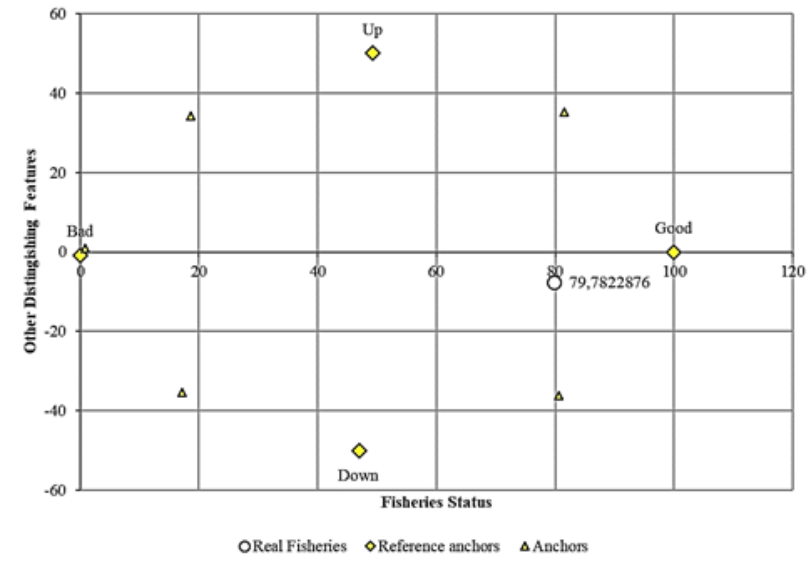

Figure 4. Sustainability Status Index of Regulatory and Institutional Dimensions

\section{Leverage Attributes}

Based on the analysis, it can be known that sensitive attributes in the dimensions that measure the sustainability status of the implementation of waste banks in The Rafi' Elementary School Waste Bank in Bandung City can be seen in Tabel 3.

Table 3. Leverage Analysis on Sustainability Status for Ecological Dimension

\begin{tabular}{clc}
\hline No. & \multicolumn{1}{c}{ Attribute } & Value \\
\hline 1 & Landuse & 13.64 \\
\hline 2 & Location to school & 9.418 \\
\hline 3 & Accessibility & 11.34 \\
\hline 4 & $\begin{array}{l}\text { Location to waste } \\
\text { sources }\end{array}$ & 19.87 \\
\hline
\end{tabular}

Table 4. Leverage Analysis on Sustainability Status for Economical Dimension

\begin{tabular}{clc}
\hline No. & \multicolumn{1}{c}{ Attribute } & Value \\
\hline 1 & Diversification & 5.85 \\
\hline 2 & $\begin{array}{l}\text { Economical advantage } \\
\text { for community }\end{array}$ & 8.18 \\
\hline 3 & Profit generation & 8.24 \\
\hline 4 & Support from private & 5.82 \\
\hline 5 & $\begin{array}{l}\text { Support from } \\
\text { government }\end{array}$ & 5.93 \\
\hline 6 & $\begin{array}{l}\text { Operation budget } \\
\text { support }\end{array}$ & 6.62 \\
\hline 7 & Investment support & 7.03 \\
\hline
\end{tabular}


Table 5. Leverage Analysis on Sustainability Status for Social Dimension

\begin{tabular}{cll}
\hline No. & \multicolumn{1}{c}{ Attribute } & Value \\
\hline 1 & $\begin{array}{l}\text { Teacher \& student } \\
\text { perception }\end{array}$ & 0.028 \\
\hline 2 & Transaction continuation & 0.132 \\
\hline 3 & $\begin{array}{l}\text { Teacher \& student } \\
\text { knowledge on waste } \\
\text { management \& waste bank }\end{array}$ & 0.032 \\
\hline 4 & $\begin{array}{l}\text { Frequency of knowledge } \\
\text { enforcement }\end{array}$ & 0.007 \\
\hline 5 & $\begin{array}{l}\text { Percentage of community } \\
\text { involvement }\end{array}$ & 0.032 \\
\hline 6 & $\begin{array}{l}\text { Waste bank system } \\
\text { participation }\end{array}$ & 0.132 \\
\hline 7 & $\begin{array}{l}\text { Involvement of teacher and } \\
\text { student in waste bank } \\
\text { development }\end{array}$ & 0.017 \\
\hline
\end{tabular}

Table 6. Leverage Analysis on Sustainability Status for Regulation and Policy Dimension

\begin{tabular}{clc}
\hline No. & \multicolumn{1}{c}{ Attribute } & Value \\
\hline 1 & $\begin{array}{l}\text { Standard of Operation and } \\
\text { Procedure }\end{array}$ & 5.87 \\
\hline 2 & Institution of waste bank & 7.66 \\
\hline 3 & Regulation stability & 20.22 \\
\hline 4 & $\begin{array}{l}\text { Legal documentation from } \\
\text { head of school }\end{array}$ & 3.84 \\
\hline
\end{tabular}

- Ecological Dimensions contain attributes of the waste banks location close to the source of waste (RMS $=19.87$ ) and land use rates around waste banks (RMS = 13.64) as leverage to support the sustainability of the implementation of waste banks. The dimensions of the Ecological aspect have an MDS index value of 80.02. The location of school-based waste banks only has a potential source of waste from the school environment, which is limited in the type and amount of the incidence, so that the waste saved is relatively small. In addition, the level of land use around the waste bank is mostly used for teaching and learning activities so that the room used by the waste bank is relatively small. Nevertheless, the application of waste banks that are part of the
3R principle has economic benefit value and has an effect on the behavior of learners in managing waste so that it will be able to reduce the volume of waste dumped into the final waste processing site.

- The economic dimension has the attributes of the benefits of waste bank management (RMS=8.24), community/ student economic benefits $\quad(\mathrm{RMS}=8.18), \quad$ government investment cost support (RMS=7.03), private/NGO investment cost support (RMS=6.62), O\&P cost support from the government $(\mathrm{RMS}=5.93)$, waste bank has other diversification $(\mathrm{RMS}=5.85)$, and $\mathrm{O} \& \mathrm{P}$ fee support from private/NGO $(\mathrm{RMS}=5.82)$ as leverage supports sustainability of waste bank implementation. The MDS index value is 26.95. Income from waste bank management is generally unreliable for the routine operation and maintenance of waste banks. School-based waste banks generally self-finance the management of their waste banks, relying only on transactions that occur between garbage banks and customers with inadequate quantities. Based on these conditions, investment and O\&P cost support, both from the government and private / NGOs is needed by school-based waste bank managers. Government support can be through school sanitation programs while from private parties / NGOs through CSR programs.

- The Social Dimension has the attributes of customer continuity in saving (RMS = 0.132 ), and the participation of all elements of school society (teachers and students) in building a waste management system (RMS $=0.132)$ as leverage to support the sustainability of the implementation of waste banks and has an MDS index value of 49.88. Continuity of customers saving consistently and the participation of all elements of the school community in building a waste management system tends to be low, greatly 
affecting the sustainability of the implementation of waste banks. Based on these conditions, the increase in the capacity of teachers and students in community-based waste management using the waste bank approach needs to be done programmatically and continuously.

- The Regulatory and Institutional dimensions contain the attributes of legal stability that regulates (local regulations and mayoral regulations in waste management) (RMS = 20.22), as leverage supporting the sustainability of the implementation of waste banks. The Regulatory and Institutional aspect dimension has an MDS index value of 79.78. Regulations and legislation that become protections in the application of waste banks in Indonesia are quite complete, both on a national, provincial and district/city scale, but many have not been implemented in the field.

\section{Conclusion}

Sensitive attributes affect the application of waste banks in Rafi' Elementary School there are 12 attributes, namely from dimensions: (a) Ecology (location of waste banks close to the source of waste and land use rates around garbage banks); (b) The economy (benefits from waste bank management, community/students benefiting economically, investment cost support from the government, investment cost support from private/NGO, O\&P cost support from the government, waste banks have other diversification, and $\mathrm{O} \& \mathrm{P}$ cost support from private/NGO); (c) Social (continuity of customers in saving, and participation of all elements of school society (teachers and students) in building waste management systems), (d) Regulations and Institutions (legal stability governing, local regulations and mayoral regulations in waste management).

\section{Recommendation}

The research conducted only reached the stage of assessment of sustainability index and determination of sustainability status, therefore it is necessary to conduct further research that is policy analysis that needs to be done to improve the sustainability of waste banks in schools. The approaches that can be used are Participatory Prospective Analysis and System Dynamics Model.

\section{Acknowledgement}

This research was financially support by the Faculty of Engineering, Universitas Pasundan for 2020-2021 periods. High appreciation also convey to Ar Rafi' Elementary School teachers and staffs, as well as all expert respondents.

\section{References}

Nababan, B.O., Sari, Y.D., Hermawan, M. (2007). Analisis Keberlanjutan Perikanan Tangkap Skala Kecil di Kabupaten Tegal Jawa Tengah. J. Bijak dan Riset Sostek KP, 2(2): 137-158.

Walker, C. \& Baxter, J. (2019). Method Sequence and Dominance in Mixed Methods Research: A Case Study of the Social Acceptance of Wind Energy Literature. International Journal of Qualitative Methods, $18: 1-4$.

Triana, A.P. \& Sembiring, E. Evaluasi Kinerja dan Keberlanjutan Program Bank Sampah sebagai Salah Satu Pendekatan dalam Pengelolaan Sampah dengan Konsep 3R. Jurnal Teknik Lingkungan, 24(2): 69-78.

Yustiani, Y.M., Rochaeni, A. \& Aulia, E. (2019). Konsep Pengelolaan Sampah di Desa Babakan, Kabupaten Bandung. EnviroScienteae, 15 (1), pp. 121-126.

Yustiani, Y.M., Abror, D.F. (2019). Operasional Bank Sampah Unit dalam Pengelolaan Sampah Perkotaan. JURNALIS: Jurnal Lingkungan dan Sipil. Vol. 2 (2), pp.82-89. 